\title{
Time has Come to Eradicate Leprosy and Tuberculosis from India: Way Forward
}

\author{
Saroj Chooramani Gopal ${ }^{1}$ \\ ${ }^{1}$ Department of Pediatric Surgery, Institute of Medical Sciences, \\ Banaras Hindu University, Varanasi, Uttar Pradesh, India
}

Ann Natl Acad Med Sci (India) 2021;57:185-185.

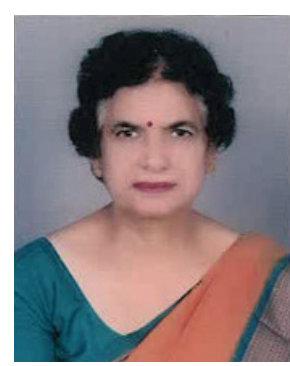

Saroj Chooramani Gopal
India has always been a country full of diversities and amazing capabilities in adversities. Today in the field of medical education, on the front of growth and development and sustenance of economics, it has done reasonably well. The Government at the Centre and even in the states has been proactive in tackling the health challenges, amalgamating the private public partnership. Being a country home to nearly one-sixth of the world population, we owe a real big responsibility to care for health of people. Amply emphasized in all the treatise of medicine "Prevention is Better than Cure and is more Economic," hence focus and investment on this strategy is worth. Development of vaccines has been the most potent weapon to prevent and eradicate a disease. Edward Jenner's observational ingenuity and perseverance, led to the introduction of small pox vaccine. The joint resolve of WHO and world community to go for en-mass vaccination of its people to protect from smallpox, not only saved countless lives and morbidity but the dreaded disease which was afflicting humanity for over three thousand years, disappeared from the world. Similar is the success story of Polio Eradication through mass vaccination program involving the whole world community as one. In spite of so many victories over so many diseases, yet the struggle will always continue. The COVID-19 pandemic has been a terrible jolt to the whole world, rich or poor alike, causing a big halt in almost every one's life. With astounding leadership provided by our Prime Minister Shri Narendra Modiji and tremendous scientific, social, and philanthropic will of our country and the whole world, we are sure to win over the COVID-19 menace in a short time as never witnessed before. Here also, vaccination against COVID-19 is the main tool in containing this pandemic.

However, the great worry for India is to have its face down in the world community when being quoted that $60 \%$ of the world's leprosy and $30 \%$ of Tuberculosis (TB) patients are from India. ${ }^{1,2}$ India has to take it as a challenge to eradicate Leprosy and TB from the country. Our Prime Minister has set the target for TB by 2025, indeed a mammoth task. These two diseases are not only sharing causative lineage of closely related pathogen MYCOBECTERIUM family but their prevalence and nature of affecting poor people living in poor environment is also alike. The drug therapy is also alike and the regimen has also to be long lasting. The BCG vaccination strategy has considerably contained childhood TB, but this vaccine does not have significant effect on prevention or treatment of adult TB or Leprosy.

But coupled with chemotherapy, if we use the potent vaccine prepared from Mycobacterium indicus pranii (GP Talwar), well proven scientifically, to be potent immune enhancer for leprosy and $\mathrm{TB}^{2,3}$ more effective than BCG, already being marketed by Cadela India. There is a need to use this vaccine as an adjunct in treatment of MDR-TB and Leprosy patients through a dedicated task force, making it a model for implementation in the areas where the disease is prevalent. The concerted efforts are likely to be able to bring desired results. The results analyzed and if found successful will serve as a role model to be followed in the country and elsewhere, to make it possible to eradicate TB and Leprosy from India. The country can emerge as a leader in tackling these two rampant diseases afflicting humanity for centuries.

\section{References}

1 Khire A, Panwalkar P. After 36 years of testing, Indian-made leprosy vaccine finally set for large roll-out. Available at: https://theprint.in/health/after-36-years-of-testing-indianmade-leprosy-vaccine-finally-set-for-large-roll-out/268394/

2 Shrivastava JP, Shrivastava A. Short Communication: Scenario of Tuberculosis in India. J Lung Pulm Respir Res 2021;8(2):24-25

3 World's first Leprosy Vaccine developed in India, Aug 20, 2016. Available at: http://timesofindia.indiatimes.com/articleshow/53788765.cms?utm_source=contentofinterest\&utm medium=text\&utm_campaign=cppst

\author{
Address for correspondence \\ Saroj Chooramani Gopal, \\ MS, MCh, FAMS, \\ President, National Academy of \\ Medical Sciences (India), \\ Siddh-Saroj Kunj, Rashmi Nagar, Lanka, \\ Varanasi 221005, Uttar Pradesh, India \\ (e-mail: sarojchooramani@gmail.com).
}

DOI https://doi.org/ $10.1055 / \mathrm{s}-0041-1740407$ ISSN $0379-038 \mathrm{X}$ (c) 2021. National Academy of Medical Sciences (India).

This is an open access article published by Thieme under the terms of the Creative Commons Attribution-NonDerivative-NonCommercial-License, permitting copying and reproduction so long as the original work is given appropriate credit. Contents may not be used for commercial purposes, or adapted, remixed, transformed or built upon. (https://creativecommons.org/licenses/by-nc-nd/4.0/).

Thieme Medical and Scientific Publishers Pvt. Ltd. A-12, 2nd Floor, Sector 2, Noida-201301 UP, India 